\title{
APLIKASI PELAYANAN PUBLIC ADDRESS SYSTEM BADAN USAHA BANDAR UDARA HANG NADIM BATAM BERBASIS WEB
}

\author{
Muhammad Hasbie ${ }^{1}$ \\ 1,2,3 Universitas Ibnu Sina Batam; JL.Teuku Umar - Pelita - Lubuk Baja, Batam,Riau \\ Island - Indonesia, (0778) 425391 \\ ${ }^{3}$ Program Studi Teknik Informatika, Universitas Ibnu Sina, Batam \\ e-mail: ${ }^{1} 1610128262202 @$ uis.ac.id
}

Penelitian ini bertujuan membangun sebuah sistem atau aplikasi untuk mempermudah pihak pengelola Bandara yaitu BUBU BP Batam, dalam memonitoring pengguna PAS yang ada di areal Bandara Hang Nadim Batam, dan meningkatkan kualitas pelayanan permohonan PAS bagi masyarakat ataupun pekerja dalam pengajuan kepemilikan PAS Bandara. Dengan konsep metode Software Development Life Cycle (SDLC) model waterfall oleh Rosa. A, dan Shalahuddin, (2018) yang memiliki empat tahapan yaitu Analisa kebutuhan perangkat lunak, desain, kode, dan pengujian sistem karena bagi penulis konsep tersebut lebih mudah dipahami untuk pengembangan sistem. Dan penggunaan sebelas diagram UML (Unified Modeling Language) yang terdiri dari Use case Diagram, Activity Diagram, Sequence Diagram, Class Diagram, Object Diagram, Deployment Diagram,Communication Diagram, State Machine/State Chart Diagram, Package diagram, Component Diagram, Interaction Overview Diagram dapat membantu penulis mendeskripsikan setiap proses interaksi data pada Aplikasi PAS. Aplikasi ini sangat bermanfaat bagi admin screening dan admin Avsec dalam pengelolaan data pemohon PAS, dengan tampilan framework Boostrap cukup membantu pengguna sistem dalam penggunaannya. Dan peningkatan sistem pengingat dan keamanan dalam pengembangan sistem dapat dijadikan referensi bagi peneliti selanjutnya, dengan kombinasi mobile app agar sistem lebih fleksibel.

Kata kunci - Kartu Identitas PAS, UML, Bandara Hang Nadim.

\begin{abstract}
This research to build a system or application to facilitate the airport management, namely BUBU BP Batam, in monitoring PAS users in the area of Hang Nadim Airport in Batam, and improving the quality of PAS application services for the public or workers in submitting ownership of airport PAS. With the concept of the Software Development Life Cycle (SDLC) method, the waterfall model by Rosa. A, and Shalahuddin, (2018) which has four stages, namely software requirements analysis, design, code, and system testing because for authors the concept is easier to understand for system development. And the use of eleven UML (Unified Modeling Language) diagrams consisting of Use Case Diagrams, Activity Diagrams, Sequence Diagrams, Class Diagrams, Object Diagrams, Deployment Diagrams, Communication Diagrams, State Machine / State Chart Diagrams, Package diagrams, Component Diagrams, Interaction Overview The diagram can help the author describe each data interaction process in the PAS application. This application is very useful for screening admins and Avsec admins in managing data of PAS applicants, with the view that the Boostrap framework is quite helpful for system users in its use. And improving the reminder and security systems in system
\end{abstract}


development can be used as a reference for future researchers, with a combination of mobile apps to make the system more flexible.

Keywords - PAS Identity Card, UML, Hang Nadim Airport

\section{PENDAHULUAN}

Bandara Udara Hang Nadim Batam salah satu bandara Internasional di Indonesia, dengan tempat yang strategis di apit 2 (dua) negara besar yaitu Malaysia dan Singapura, yang menerapkan keamanan terhadap area bandara. Setiap titik di area bandara Hang Nadim pastinya dibatasi penggunaan area aksesnya, seperti karyawan bandara yang dapat melewati atau dapat memasuki beberapa area vital bandara, namun tidak bagi penjaga toko atau tenant, pegawai kargo, pegawai maskapai, dan lain lainnya, mereka tidak dapat memasuki area bandara secara bebas, biasanya seluruh pekerja yang berada di bandara memiliki batasan tertentu pada PAS bandara yang dipakai.

Untuk mendapatkan PAS bandara pemohon terlebih dahulu harus memenuhi seluruh persyaratan administrasi kelengkapan berkas, screening dan security awareness. PAS pada bandara Hang Nadim Batam terbagi 3 (tiga) jenis yaitu jenis PAS orang, PAS Kendaraan dan TIM (Tanda Izin Mengemudi).

Pada saat ini setiap berkas permohonan PAS yang masuk di Badan Usaha Bandar Udara (BUBU) baik secara individu atau secara kolektif dari instansi/perusahaan harus mencantumkan nama dan identitas perorangan pegawainya dengan melampirkan data pendukung lainnya. Lalu setelah data atau berkas pemohon masuk di BUBU, admin BUBU melakukan proses penginputan database dengan menggunakan Ms. Excel. Lalu pemohon menunggu konfirmasi dari admin BUBU via telephone yang tercantum pada arsip. Proses penerbitan membutuhkan waktu satu minggu karena penerbitan melewati beberapa tahapan seperti admin BUBU menghubungi pihak admin perusahaan untuk memverifikasi data yang masuk apa sudah benar atau apakah karyawan yang diajukan kepengurusan PAS bandara udara sesuai dengan keperluannya, setelah verifikasi dari admin perusahaan tidak ada kendala maka admin BUBU mencetak PAS sesuai fungsinya yaitu akses yang dimiliki hanya beberapa area diantaranya (ruang tunggu/boarding pass area, cek in area, area kedatangan). Kalau proses dari perusahaan maskapai sedikit berbeda tahapannya, karena maskapai membutuhkan screening (validasi finger orang tersebut) untuk memasuki area khusus (vital) dengan pengguna PAS. dari maskapai. Sedangkan jenis PAS kendaraan harus memiliki standarisasi kendaraan yang layak masuk di area Apron (landasan/pelataran pesawat), lalu PAS TIM adalah PAS untuk para pengemudi Taksi di area bandara.

Pada pendataan PAS bandara di lapangan sering terjadinya masalah yaitu beberapa orang yang sudah memiliki PAS bandara Hang Nadim Batam yang ingin memperpanjang pengajuan PAS di bandara tidak terdata atau data tidak sesuai di Database pemilik atau pemohon PAS pada bandara Hang Nadim Batam. Dikarenakan pendataan yang dilakukan pihak Screening bandara masih menggunakan Ms. Excel, yang menyebabkan data pengguna PAS sering hilang atau kehapus. Pada saat pihak Avsec melakukan pengecekan data pemilik PAS di bandara, data yang diberikan dari pihak Screening ke pihak Avsec hanya meng-copypaste data dari Ms. Excel yang menyebabkan tidak kesesuaian dan kehilangan data pengguna atau pemohon PAS bandara.

Hal ini yang mendasari suatu ide yaitu pembuatan aplikasi pelayanan PAS bandara Hang Nadim Batam yang dapat ditampilkan dalam bentuk informasi berbasis platform web. Tujuan pembuatan sistem informasi ini untuk memudah kan proses pengajuan permohonan dan penyimpanan database pengguna PAS serta monitoring PAS yang telah beredar serta masa berlaku pengguna PAS dapat diakses oleh para petugas. 


\section{METODE PENELITIAN}

Bandara Udara Hang Nadim Batam salah satu bandara Internasional di Indonesia, dengan tempat yang strategis di apit 2 (dua) negara besar yaitu Malaysia dan Singapura, yang menerapkan keamanan terhadap area bandara. Setiap titik di area bandara Hang Nadim pastinya dibatasi penggunaan area aksesnya, seperti karyawan bandara yang dapat melewati atau dapat memasuki beberapa area vital bandara, namun tidak bagi penjaga toko atau tenant, pegawai kargo, pegawai maskapai, dan lain lainnya, mereka tidak dapat memasuki area bandara secara bebas, biasanya seluruh pekerja yang berada di bandara memiliki batasan tertentu pada PAS bandara yang dipakai.

Untuk mendapatkan PAS bandara pemohon terlebih dahulu harus memenuhi seluruh persyaratan administrasi kelengkapan berkas, screening dan security awareness. PAS pada bandara Hang Nadim Batam terbagi 3 (tiga) jenis yaitu jenis PAS orang, PAS Kendaraan dan TIM (Tanda Izin Mengemudi).

Pada saat ini setiap berkas permohonan PAS yang masuk di Badan Usaha Bandar Udara (BUBU) baik secara individu atau secara kolektif dari instansi/perusahaan harus mencantumkan nama dan identitas perorangan pegawainya dengan melampirkan data pendukung lainnya. Lalu setelah data atau berkas pemohon masuk di BUBU, admin BUBU melakukan proses penginputan database dengan menggunakan Ms. Excel. Lalu pemohon menunggu konfirmasi dari admin BUBU via telephone yang tercantum pada arsip. Proses penerbitan membutuhkan waktu satu minggu karena penerbitan melewati beberapa tahapan seperti admin BUBU menghubungi pihak admin perusahaan untuk memverifikasi data yang masuk apa sudah benar atau apakah karyawan yang diajukan kepengurusan PAS bandara udara sesuai dengan keperluannya, setelah verifikasi dari admin perusahaan tidak ada kendala maka admin BUBU mencetak PAS sesuai fungsinya yaitu akses yang dimiliki hanya beberapa area diantaranya (ruang tunggu/boarding pass area, cek in area, area kedatangan). Kalau proses dari perusahaan maskapai sedikit berbeda tahapannya, karena maskapai membutuhkan screening (validasi finger orang tersebut) untuk memasuki area khusus (vital) dengan pengguna PAS. dari maskapai. Sedangkan jenis PAS kendaraan harus memiliki standarisasi kendaraan yang layak masuk di area Apron (landasan/pelataran pesawat), lalu PAS TIM adalah PAS untuk para pengemudi Taksi di area bandara.

Pada pendataan PAS bandara di lapangan sering terjadinya masalah yaitu beberapa orang yang sudah memiliki PAS bandara Hang Nadim Batam yang ingin memperpanjang pengajuan PAS di bandara tidak terdata atau data tidak sesuai di Database pemilik atau pemohon PAS pada bandara Hang Nadim Batam. Dikarenakan pendataan yang dilakukan pihak Screening bandara masih menggunakan Ms. Excel, yang menyebabkan data pengguna PAS sering hilang atau kehapus. Pada saat pihak Avsec melakukan pengecekan data pemilik PAS di bandara, data yang diberikan dari pihak Screening ke pihak Avsec hanya meng-copypaste data dari Ms. Excel yang menyebabkan tidak kesesuaian dan kehilangan data pengguna atau pemohon PAS bandara.

Hal ini yang mendasari suatu ide yaitu pembuatan aplikasi pelayanan PAS bandara Hang Nadim Batam yang dapat ditampilkan dalam bentuk informasi berbasis platform web. Tujuan pembuatan sistem informasi ini untuk memudah kan proses pengajuan permohonan dan penyimpanan database pengguna PAS serta monitoring PAS yang telah beredar serta masa berlaku pengguna PAS dapat diakses oleh para petugas.

Penulis mencoba mengangkat judul "Aplikasi Pelayanan PAS (Public Address System)

Badan Usaha Bandar Udara Hang Nadim Batam (BUBU) Batam Berbasis Web" dengan tujuan penulis pada pengembangan sistem pelayanan PAS berbasis web ini, semoga memberikan kemudahan bagi pendaftar untuk mendapatkan cara lebih mudah untuk mendapatkan PAS, dan bagi perusahaan dapat menyimpan riwayat pemohon dan memiliki database siapa saja yang menggunakan PAS bandara di area Bandara Hang Nadim Batam. 


\section{METODE PENELITIAN}

\subsection{Analisis 5W1H}

Berikut tabel analisa Pendapat penulis yang diperlukan dalam melakukan analisis untuk mengetahui perilaku target terhadap masalah dalam penelitian ini, berdasarkan data yang sudah dihimpun penulis, berikut analisa menggunakan $5 \mathrm{~W} 1 \mathrm{H}$ :

Tabel 1 Tabel Analisa 5W1H

\begin{tabular}{|c|c|c|}
\hline 5W1H & Pertanyaan & Jawaban \\
\hline What & $\begin{array}{l}\text { - Apa target penelitian ini? } \\
\text { - Apa yang menjadi masalah yang akan } \\
\text { dijadikan untuk pembuatan Aplikasi } \\
\text { Layanan PAS Bandara Hang Nadim } \\
\text { Batam? }\end{array}$ & $\begin{array}{l}\text { - Pengembangan Sistem Pelayanan } \\
\text { Permohonan PAS (Public Area System). } \\
\text { - Belum adanya sebuah penyimpanan data } \\
\text { pemohon PAS dalam sistem berbasis online }\end{array}$ \\
\hline Who & $\begin{array}{l}\text { - Siapa Narasumber dalam penelitian } \\
\text { ini? } \\
\text { - Sasaran pengguna sistem? }\end{array}$ & $\begin{array}{l}\text { - Narasumber HRD BUBU Hang Nadim Batam } \\
\text { Bapak Enggar Adi Sulistyo } \\
\text { - Dan sasaran pengembangan sistem ini adalah } \\
\text { pemohon PAS dan pihak Bandara (Avsec) } \\
\text { dalam memonitoring Pengguna PAS }\end{array}$ \\
\hline Why & Mengapa perlunya sistem ini dibangun? & $\begin{array}{l}\text { Aplikasi dibangun agar memudahkan pemohon } \\
\text { dalam melakukan pendaftaran secara Online. }\end{array}$ \\
\hline When & Kapan penelitian dilakukan? & $\begin{array}{l}\text { Penulis melakukan penelitian dari bualn Februari } \\
2020 \text { sampai dengan Nopember } 2020\end{array}$ \\
\hline Where & Dimana penelitian ini? & $\begin{array}{l}\text { Penulis melakukan observasi dan menganalisa } \\
\text { kebutuhan dalam penelitian ini di BUBU Hang } \\
\text { Nadim Batam }\end{array}$ \\
\hline How & $\begin{array}{l}\text { Bagaimana penelitian solusi } \\
\text { permasalahan pada penelitian ini? }\end{array}$ & $\begin{array}{l}\text { Penggunaan sistem berbasis online dapat } \\
\text { membantu pemohon dalam melakukan } \\
\text { pendaftaran PAS secara online, sedangkan } \\
\text { tujuannya dalam penelitian ini diharapkan pihak } \\
\text { BUBU dapat memonitoring pengguna PAS pada } \\
\text { area Bandara Hang Nadim Batam }\end{array}$ \\
\hline
\end{tabular}

\subsection{UML}

Penulis menggunakan pemodelan sistem yaitu Unified Modeling Language (UML). Menurut Windu Gata, Grace dalam jurnal (Hendini, 2016), Unified Modeling Language (UML) adalah bahasa spesifikasi standar yang dipergunakan untuk mendokumentasikan, menspesifikasikaun dan membanngun perangkat lunak. UML merupakan metodologi dalam mengembangkan sistem berorientasi objek dan juga merupakan alat untuk mendukung pengembangan sistem.

Menurut Sukamto dan Shalahuddin (2013) dalam jurnal Sari, (2018). menjelaskan bahwa, UML terdiri dari 13 macam diagram yang dikelompokan dalam 3 kategori, Berikut 13 diagram yang merupakan beberapa jenis dari unified Modeling Language (UML) yang terbagi 3 bagian, diantaranya:

\section{Struktur Diagram}
a. Class Diagram
b. Object Diagram
c. Composite Structure Diagram
d. Component Diagram
e. Package Diagram
f. Deployment Diagram

\section{Behavior Diagram}
a. Use Case Diagram 

b. Activity Diagram
c. State Machine Diagram

3. Intecration Diagram
a. Sequence Diagram
b. Communication Diagram
c. Timing Diagram
d. Interaction Overview diagram

\subsection{Data Penelitian}

Jenis data pada pengumpulan data dalam penelitian tugas akhir ini, terdapat beberapa jenis data yaitu:

1. Data primer

Data primer merupakan data yang diterima langsung dari sumbernya, pada penelitian ini data didapat dari hasil wawancara langsung Kepala Divisi Screening PAS pada BUBU Hang Nadim Batam pada tanggal 18 Maret 2020, yang menyatakan perlunya pengembangan sistem berbasis online pada sistem pelayanan PAS di BUBU Hang Nadim Batam (Bukti wawancara Terlampir). Data wawancara tersebut menjadikan salah satu data primer penulis. Dan data primer lainnya sebagai berikut:
a. Data Wawancara Kepala Divisi Screening.

b. Data Pemohon periode 2019 s/d 2020.

2. Data Sekunder

Sedangkan Data sekunder merupakan data yang sudah diolah, data sekunder dalam penelitian tugas akhir ini sebagai berikut:

a. Jurnal dan literatur Penelitian terdahulu terkait dengan kebutuhan sistem informasi PAS.

b. Data profile BUBU sebagai tempat penulis melakukan penelitian.

\subsection{Metode Waterifall}

Dalam penelitian ini penulis menggunakan metode Waterfall (Rosa \& Shalahuddin, 2018). Dikarenakan metode waterfall dari Rosa. A dan Shalahuddin lebih ringkas dan mudah dipahami oleh penulis. Menurut Rosa \& Shalahuddin, (2018). Metode air terjun (Waterfall) sering juga disebut model sekuensial linier (Sequential Linear) atau alur hidup klasik (Classic Life Cycle). Dalama metode ini Rosa. A dan Shalahuddin menggunakan empat metode yaitu analisis, desain, pengodean, dan pengujian.

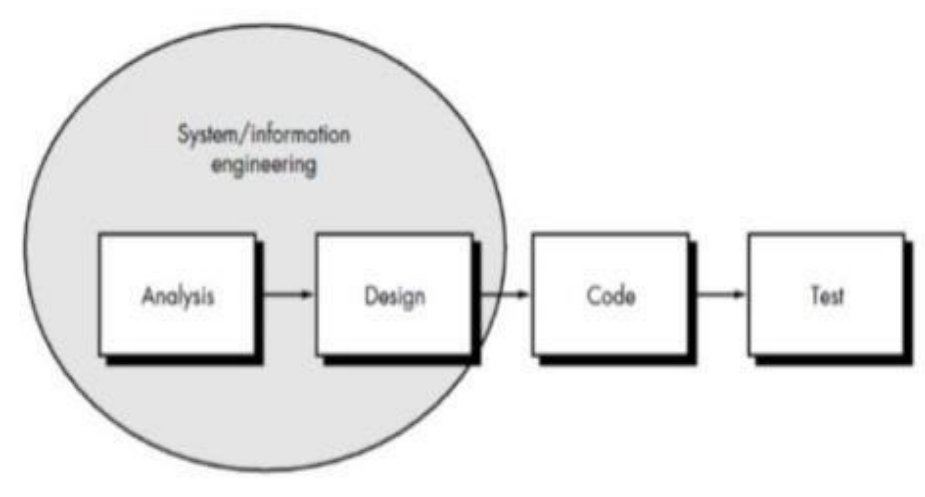

Gambar 1 Metode Waterfall (Rosa A dan Shalahuddin, 2018:28) 
Berdasarkan pendapat Rosa dan Shalahuddin pada jurnal (Nadira et al., 2020) metode waterfall memiliki 4 (empat) tahapan, yaitu sebagai berikut:

1. Analisa Kebutuhan Perangkat Lunak

Proses pengumpulan kebutuhan secara insentif untuk menspesifikasikan kebutuhan perangkat lunak agar dapat dipahami perangkat lunak seperti apa yang dibutuhkan oleh user.

2. Desain

Desain perangkat lunak adalah proses multi langkah yang fokus pada desain pembuatan program perangkat lunak termasuk struktur data, arsitektur perangkat lunak, representasi antarmuka dan prosedur pengkodean. Tahap ini mentranslasi kebutuhan perangkat lunak dari tahap analisis kebutuhan ke representasi desain agar dapat diimplementasikan menjadi program pada tahap selanjutnya.

3. Pembuatan Kode Program

Desain harus ditranslasikan ke dalam program perangkat lunak. Hasil dari tahap ini adalah program komputer sesuai dengan desain yang telah dibuat pada tahap desain

4. Pengujian

Pengujian berfokus pada perangkat lunak secara dari segi logik dan fingsional dan memastikan bahwa semua bagian sudah diuji.

\subsection{Pemodelan Bisnis}

Pemodelan merupakan sebuah gambaran pada pembangunan sistem yang mana pada penelitian ini penulis menguraikan beberapa pemodelan bisnis yang dapat diketahui proses pada perancangan atau pembangunan aplikasi Pelayanan PAS bandara, berikut proses alur data tersebut.

\subsection{Arsitektur Aplikasi}

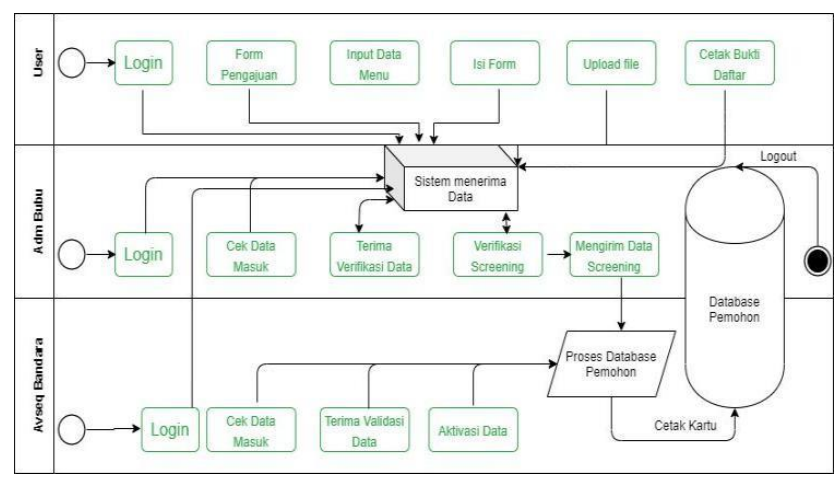

Gambar 2 Arsitektur aplikasi PAS Bandara

Arsitektur pada aplikasi PAS Bandara Hang Nadim Batam terdiri dari 3 pengguna sistem, diantaranya (pemohon PAS bandara, Admin Screening BUBU, Admin Avsec). 
Pada penelitian ini penulis menggunakan proses pada tahapan Waterfall yang mana tahapannya terdiri dari (Analisis, Desain, Pengkodean, Pengujian).

\subsection{Analisis}

Untuk mendapatkan hasil rancangan ini sesuai dengan kebutuhan sistem yang diharapkan pengguna maka penulis melakukan analisa alur sistem berjalan apakah sistem yang sedang berjalan memiliki kekurangan dan jika memang terdapat kekurangan maka penulis melakukan analisa pada perancangan pengembangan Aplikasi sistem PAS bandara. Berikut perbedaan alur sistem yang berjalan dan alur sistem yang akan diusulkan oleh penulis yang terlihat pada gambar 3 dan 4. Dari dua alur sistem (sistem yang berjalan dengan sistem yang dusulkan) dapat diketahui ada beberapa perbandingan kelebihan dan kekurangan sistem, berikut kelebihan dan kekurangan tersebut:

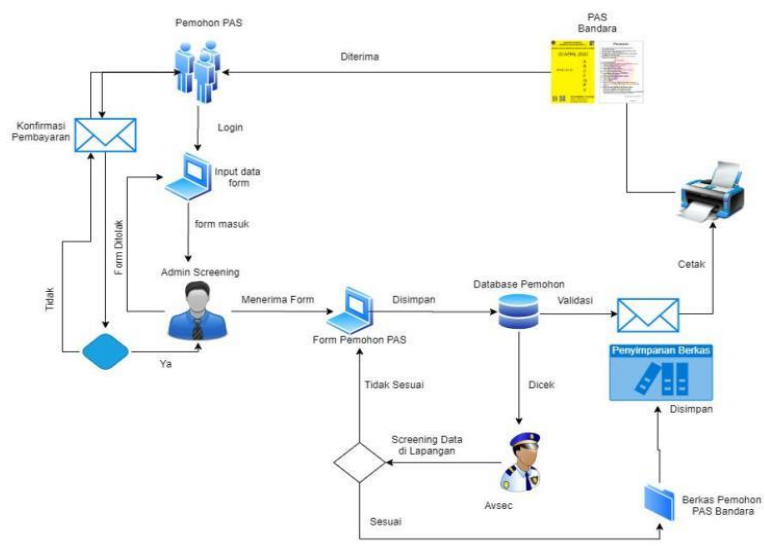

Gambar 3 Aliran Sistem Berjalan

Tabel 3 Perbandingan Sistem

\begin{tabular}{|c|c|c|c|}
\hline $\mathrm{NO}$ & Sistem & Kelebihan & Kekurangan \\
\hline 1 & $\begin{array}{l}\text { Sistem yang } \\
\text { berjalan }\end{array}$ & $\begin{array}{l}\text { a. Proses pembayaran yang langsung } \\
\text { tunai karena pembuktian } \\
\text { pembayaran langsung di tempat. } \\
\text { b. Pihak Screening lebih mengetahui } \\
\text { karakteristik orang yang } \\
\text { mengajukan pemohon PAS. }\end{array}$ & $\begin{array}{l}\text { a. Penyimpanan data kurang aman } \\
\text { karena tidak tersimpan dengan rapi } \\
\text { b. Data yang di input sering double data } \\
\text { atau kehilangan data karena } \\
\text { penyimpanan Database menggunakan } \\
\text { Ms Excel } \\
\text { c. Pihak pemohon harus menanyakan } \\
\text { langsung ke pihak BUBU untuk } \\
\text { mengetahui pengajuan PAS proses } \\
\text { nya sampai dimana } \\
\text { d. Pemberian sering lambat karena } \\
\text { percetakan PAS mengalami } \\
\text { pemeriksaan berulang antara pihak } \\
\text { Avsec dan pihak Screening karena } \\
\text { dilakukan secara manual }\end{array}$ \\
\hline 2 & $\begin{array}{l}\text { Sistem yang } \\
\text { diusulkan }\end{array}$ & $\begin{array}{l}\text { a. Penyimpanan data yang lebih aman } \\
\text { karena data tersusun rapi di } \\
\text { aplikasi Pelayanan PAS BUBU } \\
\text { hang Nadim } \\
\text { b. Peg-Input-an data tidak mengalami } \\
\text { double data karena penyimpanan } \\
\text { menggunkan Database My SQL } \\
\text { c. Pihak pemohon hanya menunggu } \\
\text { dan melihat proses pengajuan PAS } \\
\text { di aplikasi Pelayan PAS BUBU } \\
\text { Hang Nadim }\end{array}$ & $\begin{array}{l}\text { a. Pembayaran yang harus menunggu } \\
\text { dari pihak pemohon dikarenakan } \\
\text { pihak pemohon harus mengirim bukti } \\
\text { pembayaran terlebih dahulu. } \\
\text { b. Sistem apikasi harus terus terhubung } \\
\text { dengan internet. }\end{array}$ \\
\hline
\end{tabular}




\begin{tabular}{|c|c|c|}
\hline & & $\begin{array}{l}\text { d. Percetakan PAS tidak lagi } \\
\text { terlambat karena pemeriksa data } \\
\text { pemohon PAS cukup melihat di } \\
\text { aplikasi pelayanan PAS. }\end{array}$ \\
\hline
\end{tabular}

\subsection{Desain}

Diagram UML pada penelitian ini terdiri dari bagian Struktur Diagram, Behavior Diagram, Intecration Diagram, berikut diagram UML pada pengembangan sistem aplikasi Pelayanan PAS Bandara Hang Nadim Batam:

\section{A. Definisi Aktor}

Definisi aktor merupakan penjelasan apa saja yang dilakuan oleh pengguna sistem atau yang disebut pada UML adalah aktor-aktor, karena kontribusi pengguna sistem inilah yang akan mengoperasikan keseluruhan sistem aplikasi Pelayanan PAS Bandara Hang Nadim Batam berbasis $W e b$ ini, definisi aktor dapat dilihat pada tabel 4.2 dibawah ini:

Tabel 4 Definisi Aktor

\begin{tabular}{|c|l|l|}
\hline NO & \multicolumn{1}{|c|}{ Aktor } & \multicolumn{1}{c|}{ Keterangan } \\
\hline 1. & Pemohon/Admin Perusahaan & $\begin{array}{l}\text { a. Melakukan Login } \\
\text { b. Penginputan data pemohon } \\
\text { c. Upload data pemohon }\end{array}$ \\
\hline 2. & Admin Screening BUBU & $\begin{array}{l}\text { a. Login pada sistem } \\
\text { b. Akses penuh pada aplikasi karena peranan penting } \\
\text { dalam keseluruhan pengelolaan data pada sistem } \\
\text { (Insert, Update dan delete) }\end{array}$ \\
\hline 3. & Admin Avsec & $\begin{array}{l}\text { a. Melakukan Login } \\
\text { b. Mengatur jadwal Screening pada pemohon PAS }\end{array}$ \\
\hline
\end{tabular}

\subsubsection{Use Case Diagram}

Diagram Use Case dari sistem informasi aplikasi pengajuan Pelayanan PAS Bandara Hang Nadim Batam adalah sebagai berikut:

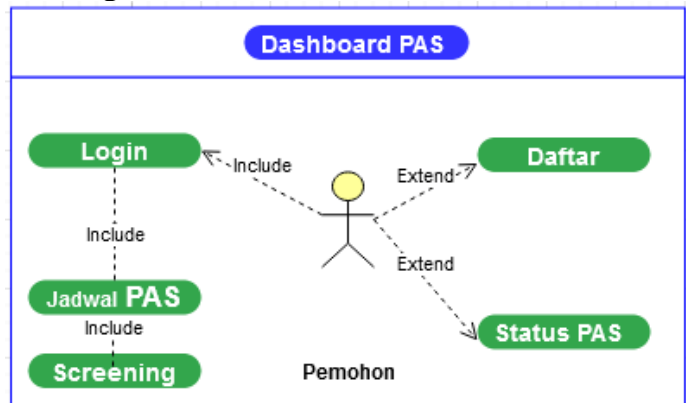

Gambar Use Case Diagram keseluruhan pada aplikasi PAS

1. Use Case Admin Perusahaan (Pemohon)

Pemohon atau admin perusahaan adalah aktor yang akan diolah oleh sistem dalam komponen informasi data kepemilikan PAS Bandara Hang Nadim Batam, berikut Use Case Pemohon PAS:

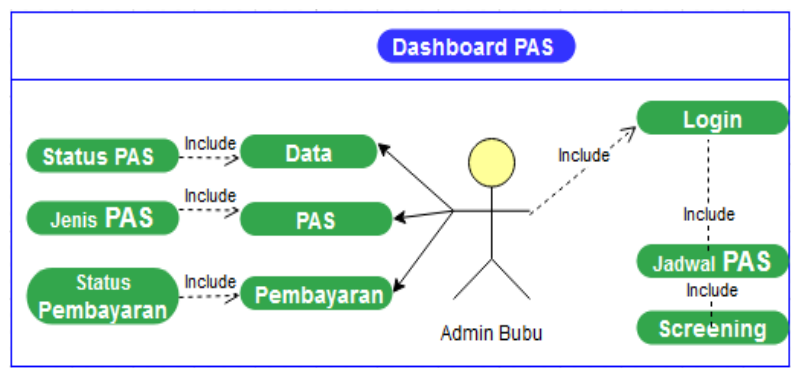


Gambar 6 Use Case Diagram Pemohon(Admin Perusahaan)

2. Use Case Admin Screening BUBU

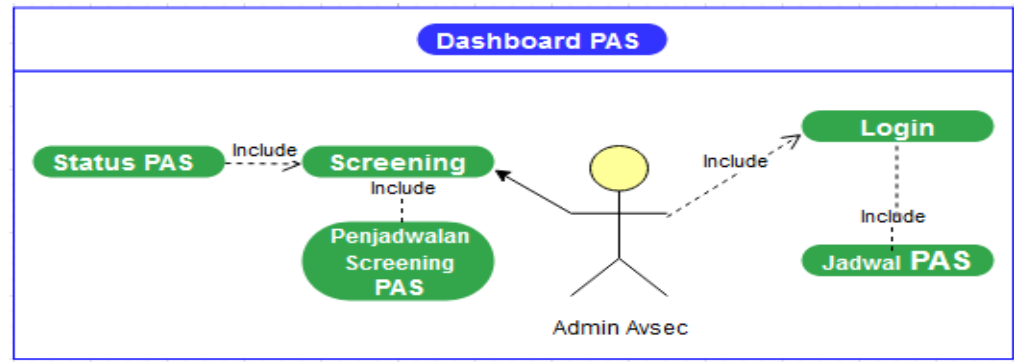

Gambar 7 Use Case Admin Screening BUBU

3.2.2 Activity

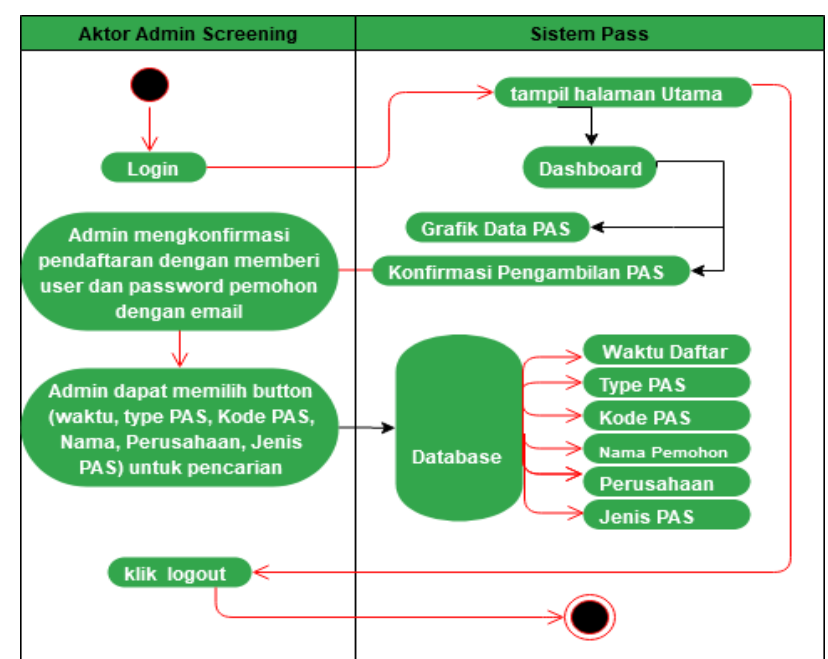

Diagram

1. Activity Diagram Pemohon

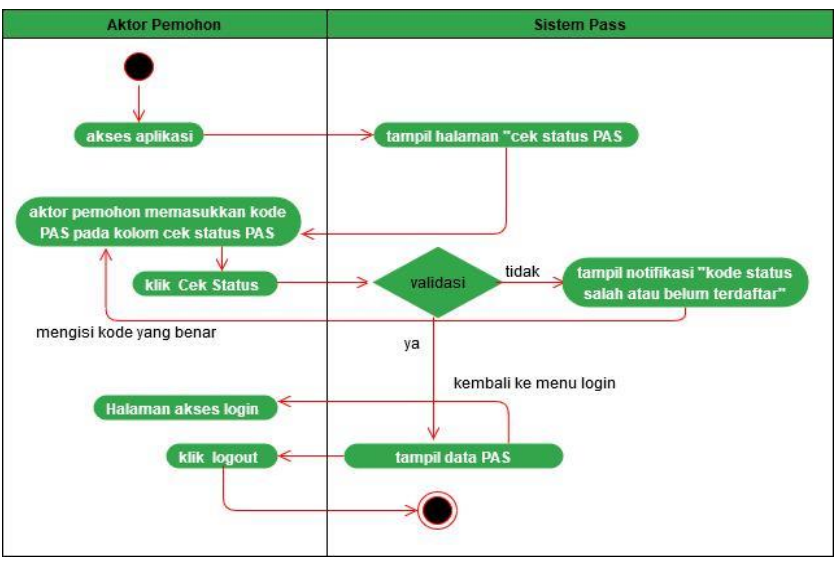

Gambar 9 Activity Diagram Pemohon 
2. Activity Diagram Avsec

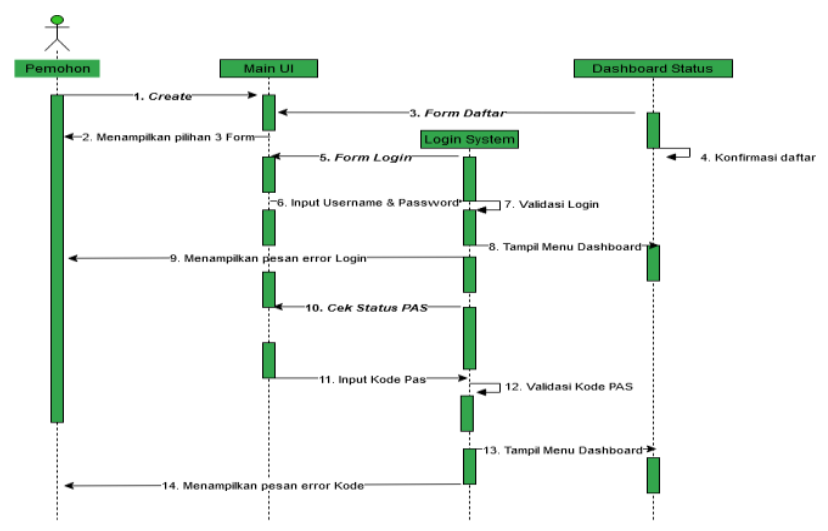

Gambar 11 Activity Diagram Admin Avsec

\subsubsection{Sequence Diagram}

1. Sequence Pemohon

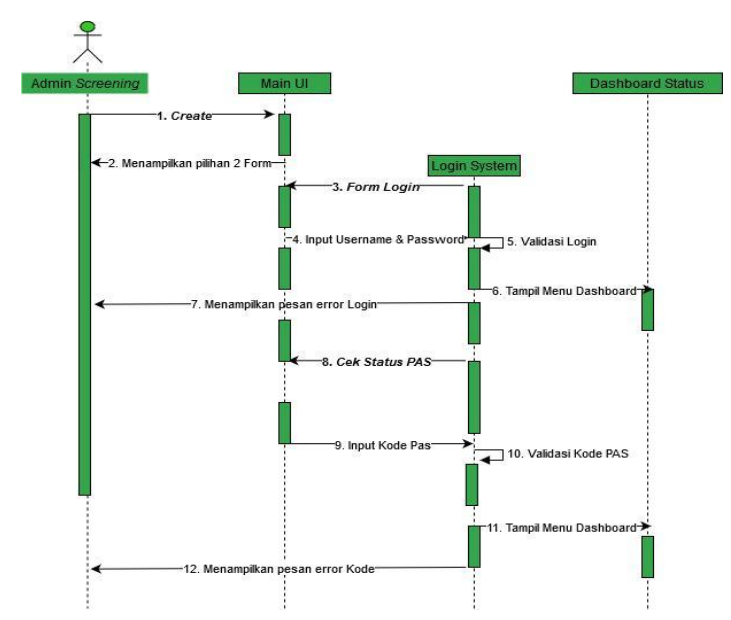

Gambar 12 Sequence Diagram Menu Pemohon

2. Sequence Admin Screening

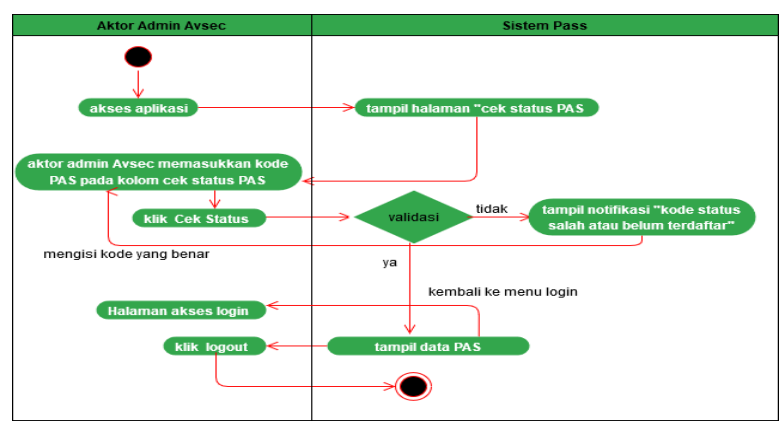

Gambar 13 Sequence Diagram Admin Screening BUBU 
3. Sequence Admin Avsec

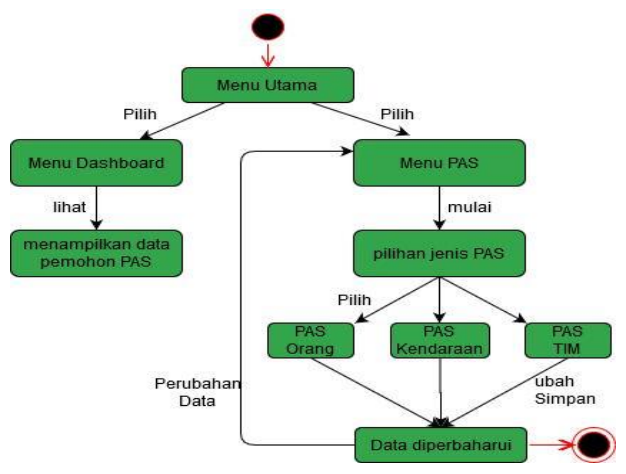

Gambar 14 Sequence Diagram Admin Avsec

\subsubsection{Statechart Diagram}

1. State Diagram Pemohon

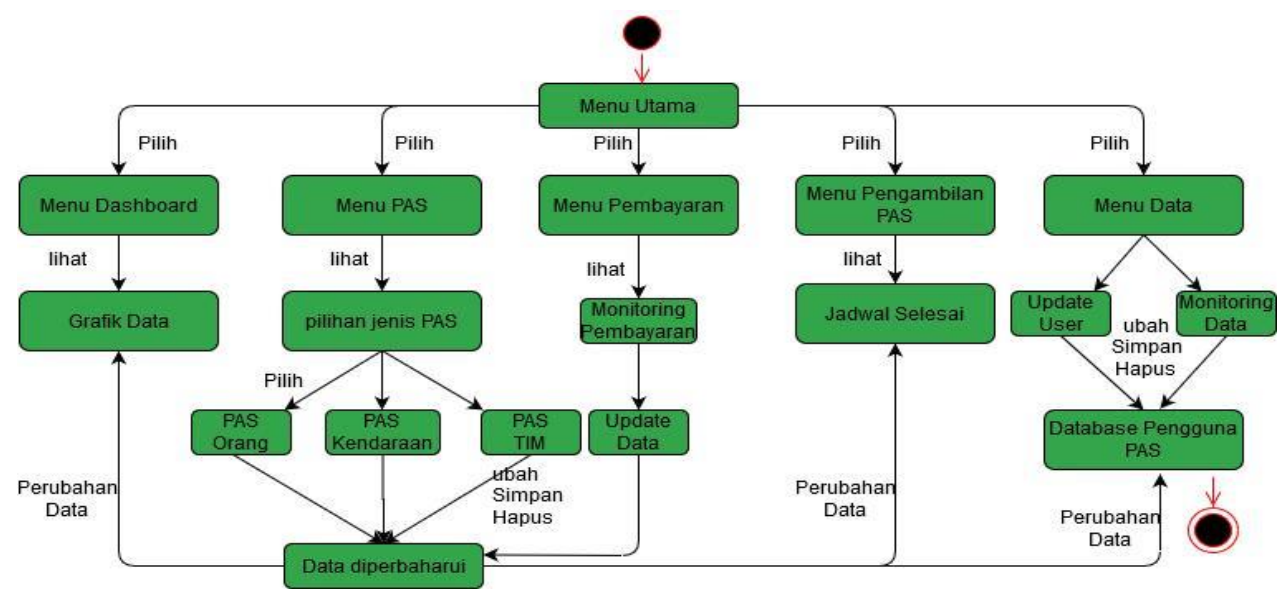

Gambar 15 Statechart Diagram Menu Pemohon

2. State Diagram Admin Screening BUBU

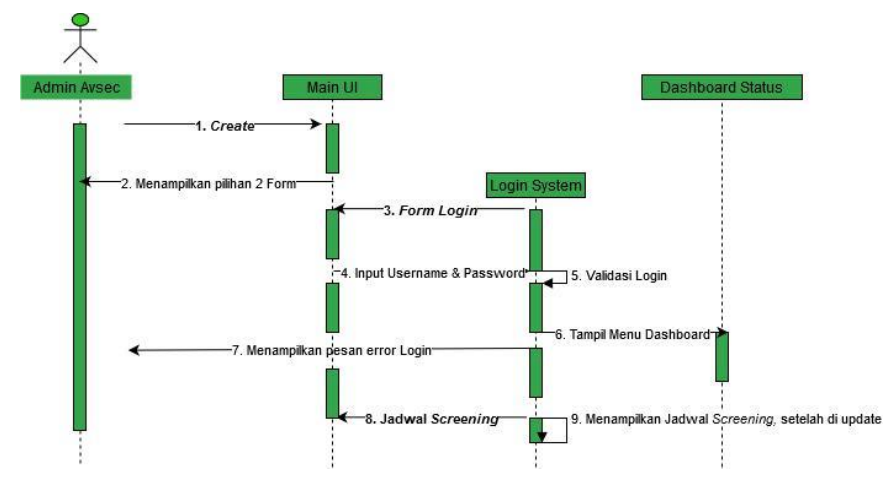

Gambar 16 Statechart Diagram Menu Admin Screening 
3. State Diagram Avsec

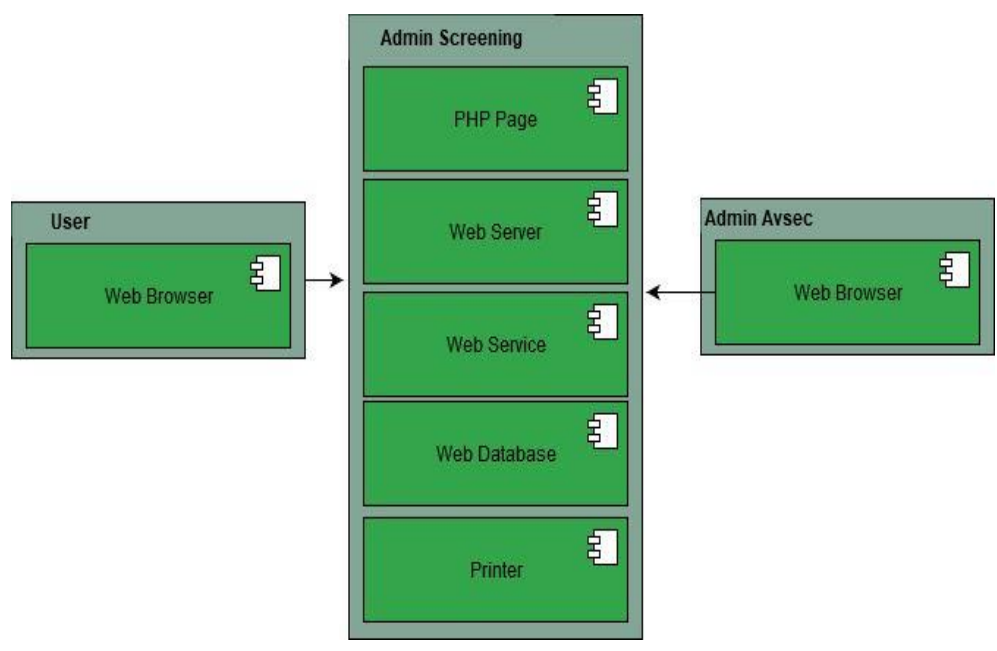

Gambar 1743 Statechart Diagram Menu Admin Avsec

\subsubsection{Deployment Diagram}

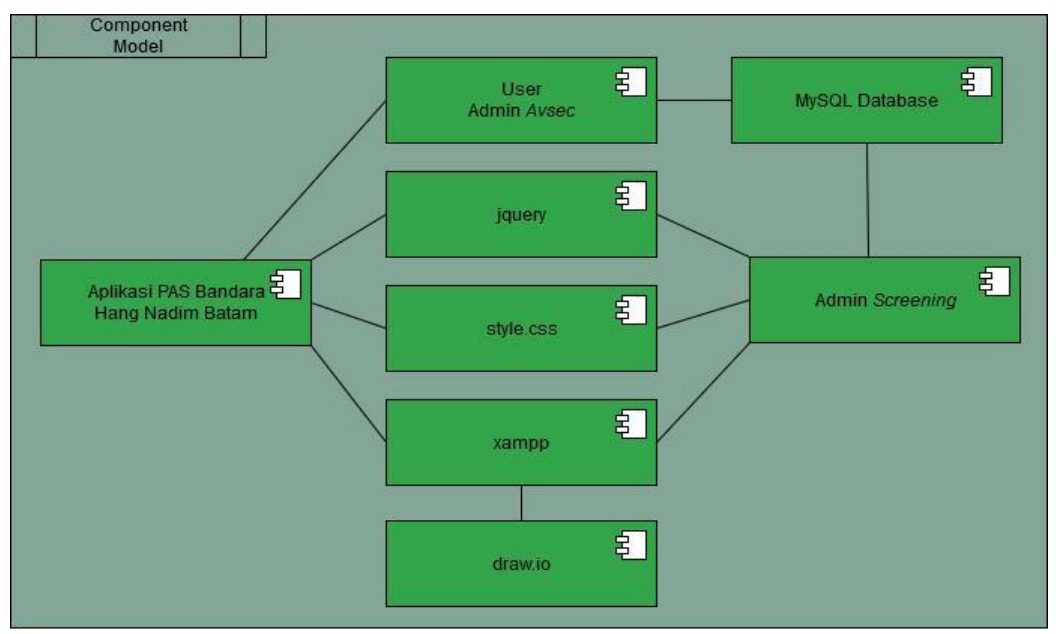

Gambar 18 Deployment Diagram Aplikasi Pemohon PAS

\subsubsection{Component Diagram}

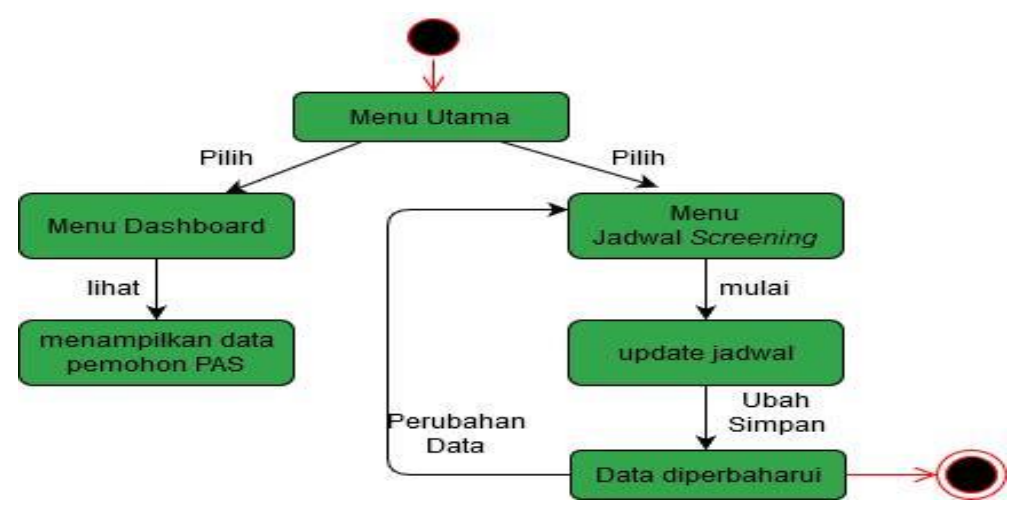

Gambar 20 Component Diagram Aplikasi Pemohon PAS 


\subsubsection{Package Diagram}

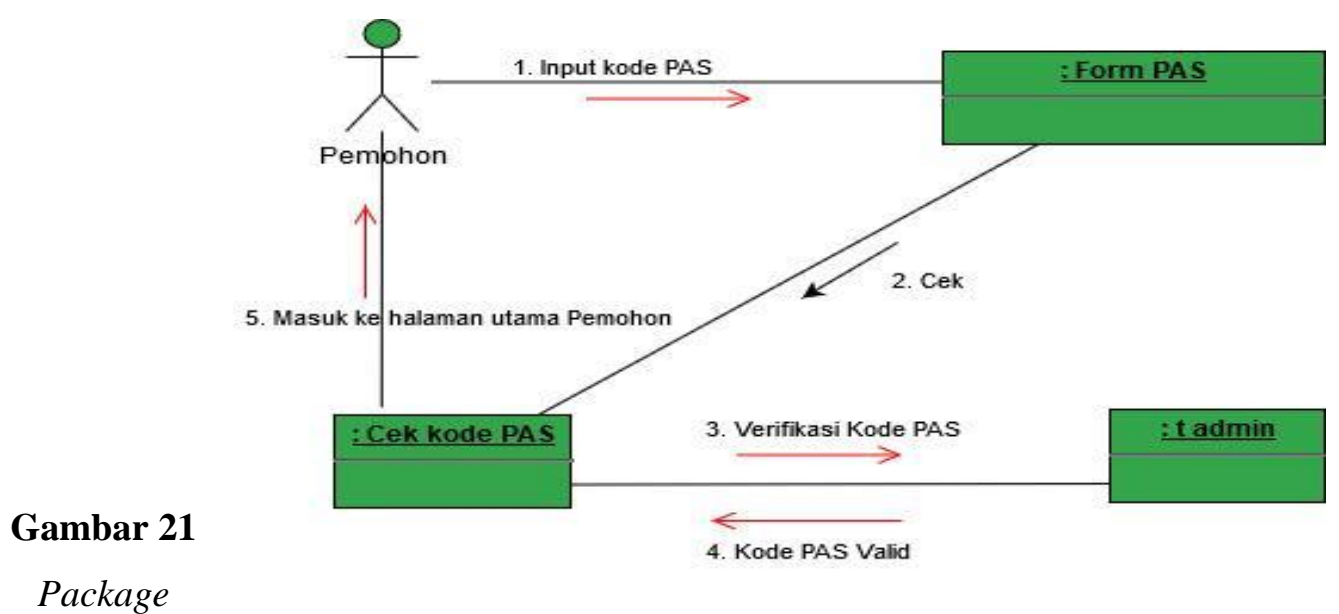

Diagram Aplikasi Pemohon PAS

\subsubsection{Collaboration Diagram}

1. Collaboration Diagram Pemohon

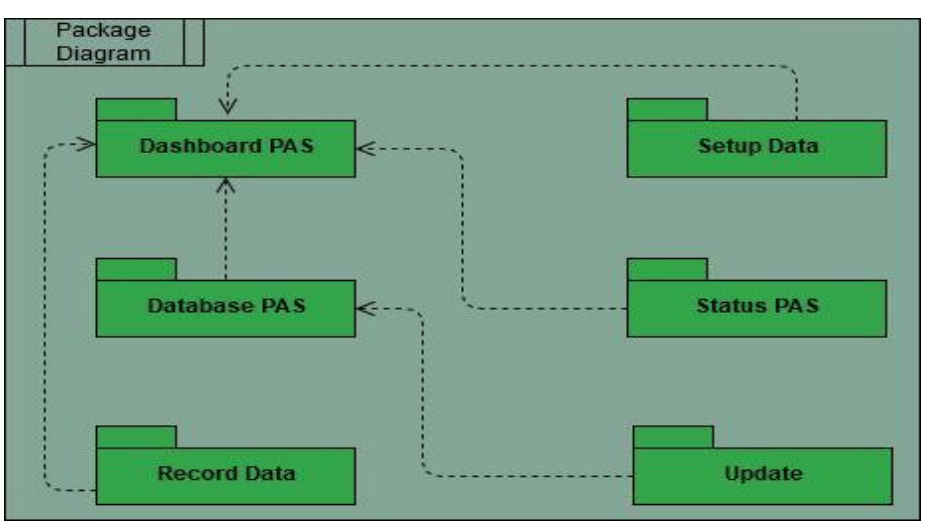

Gambar 22 Collaboration Diagram Aplikasi Pemohon PAS 


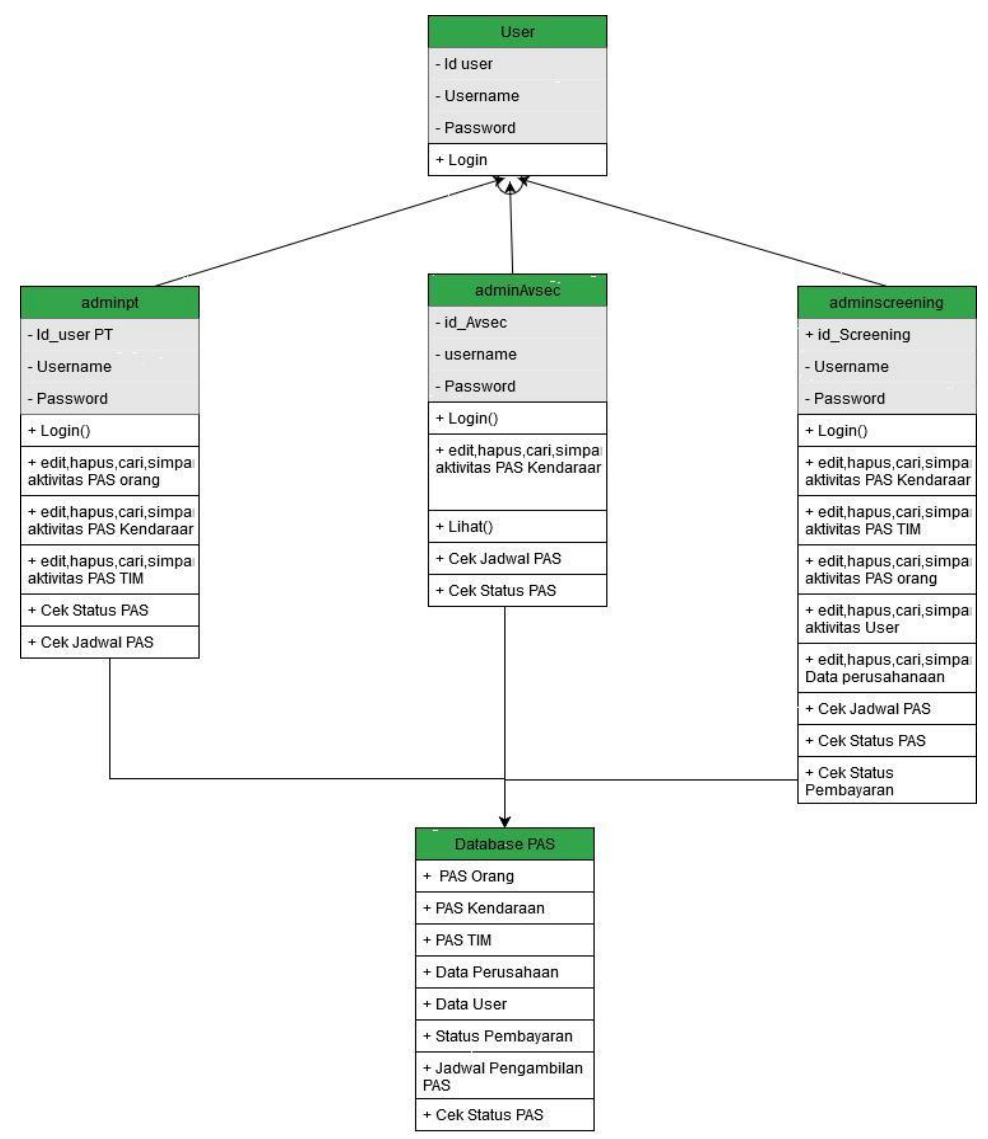

Gambar 24 Collaboration Diagram Tambah Data Pengambilan PAS

\subsection{Pengujian}

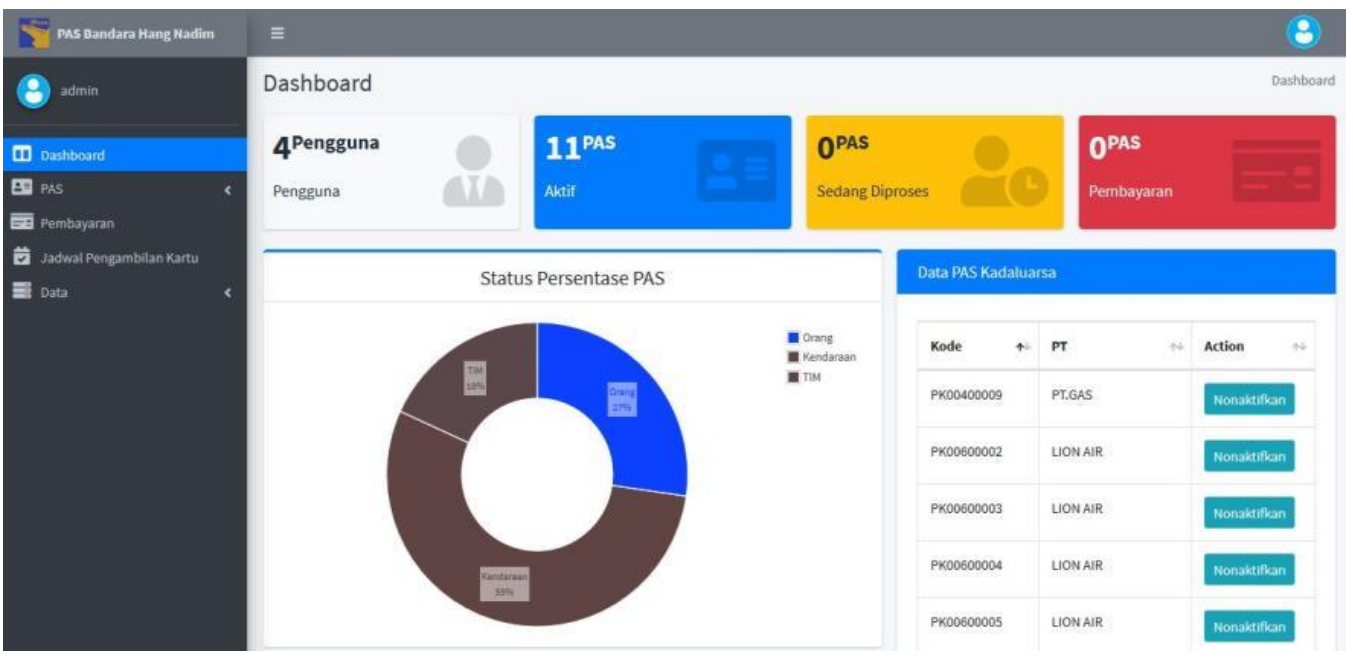

Gambar Implementasi Interface Dashboard Admin Screening 


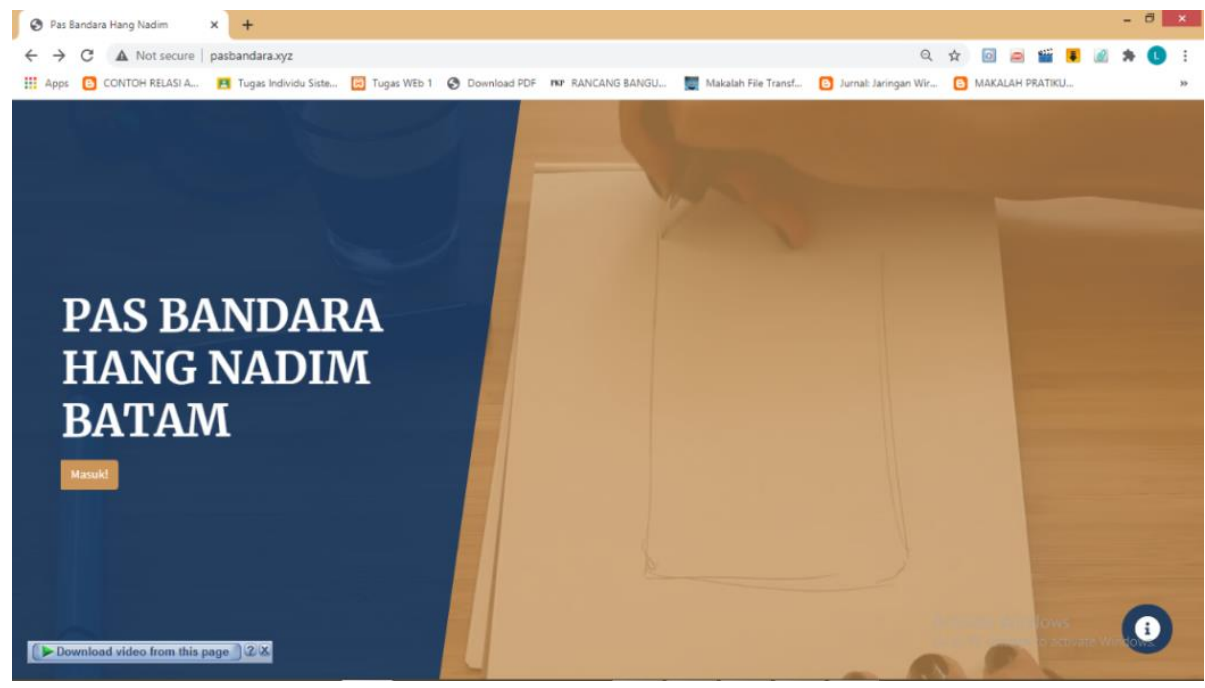

Gambar Tampilan Portal pada Aplikasi Pelayanan PAS

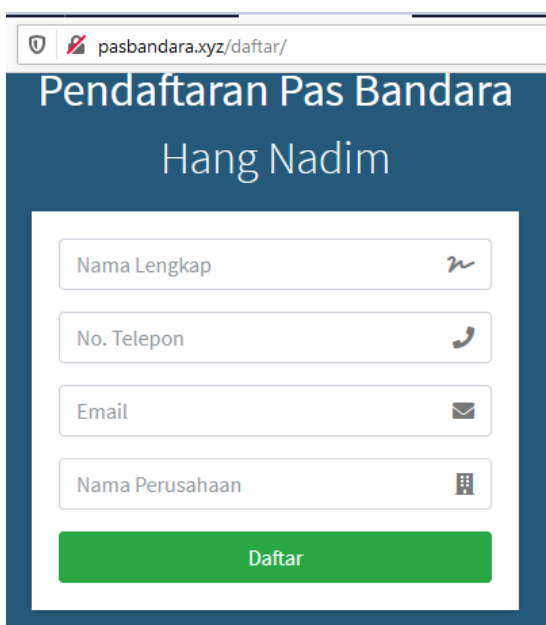

Gambar Tampilan Daftar pada Aplikasi Pelayanan Permohon PAS

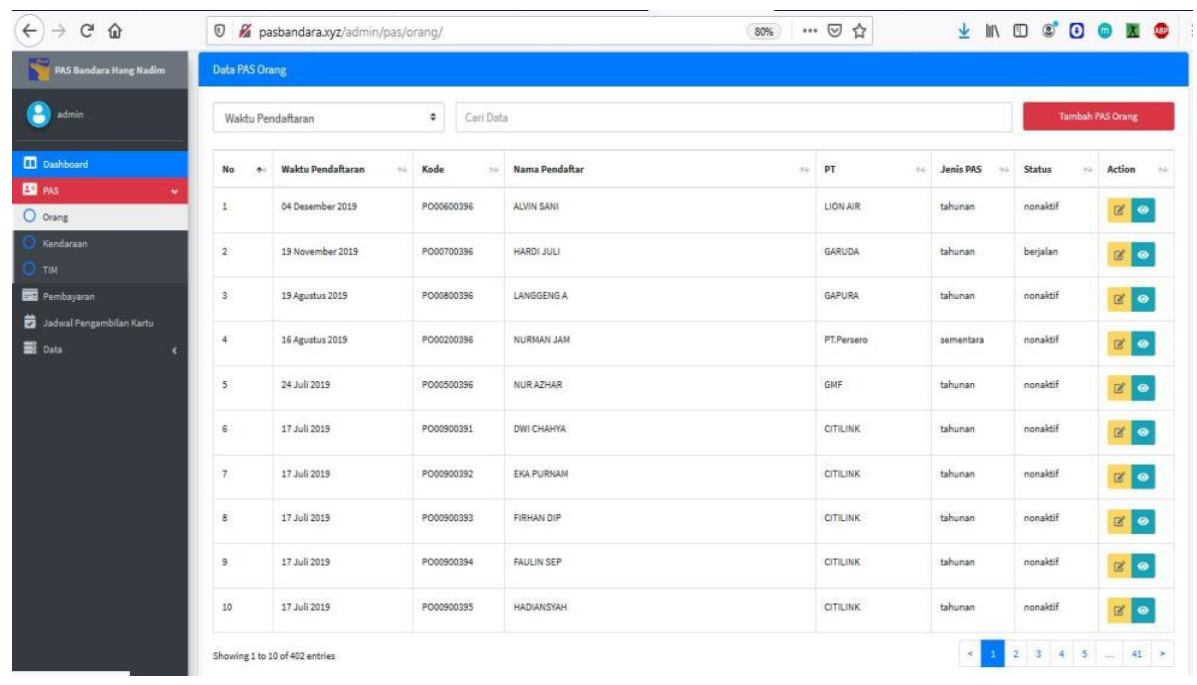

Gambar Halaman Database Jenis PAS Orang 


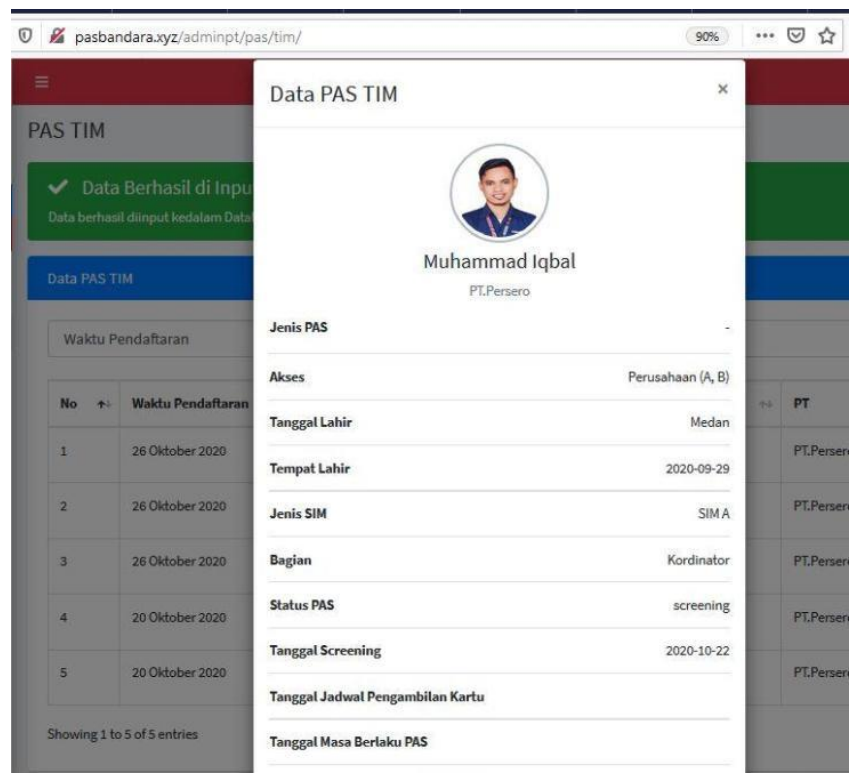

Gambar Halaman Profile Data PAS
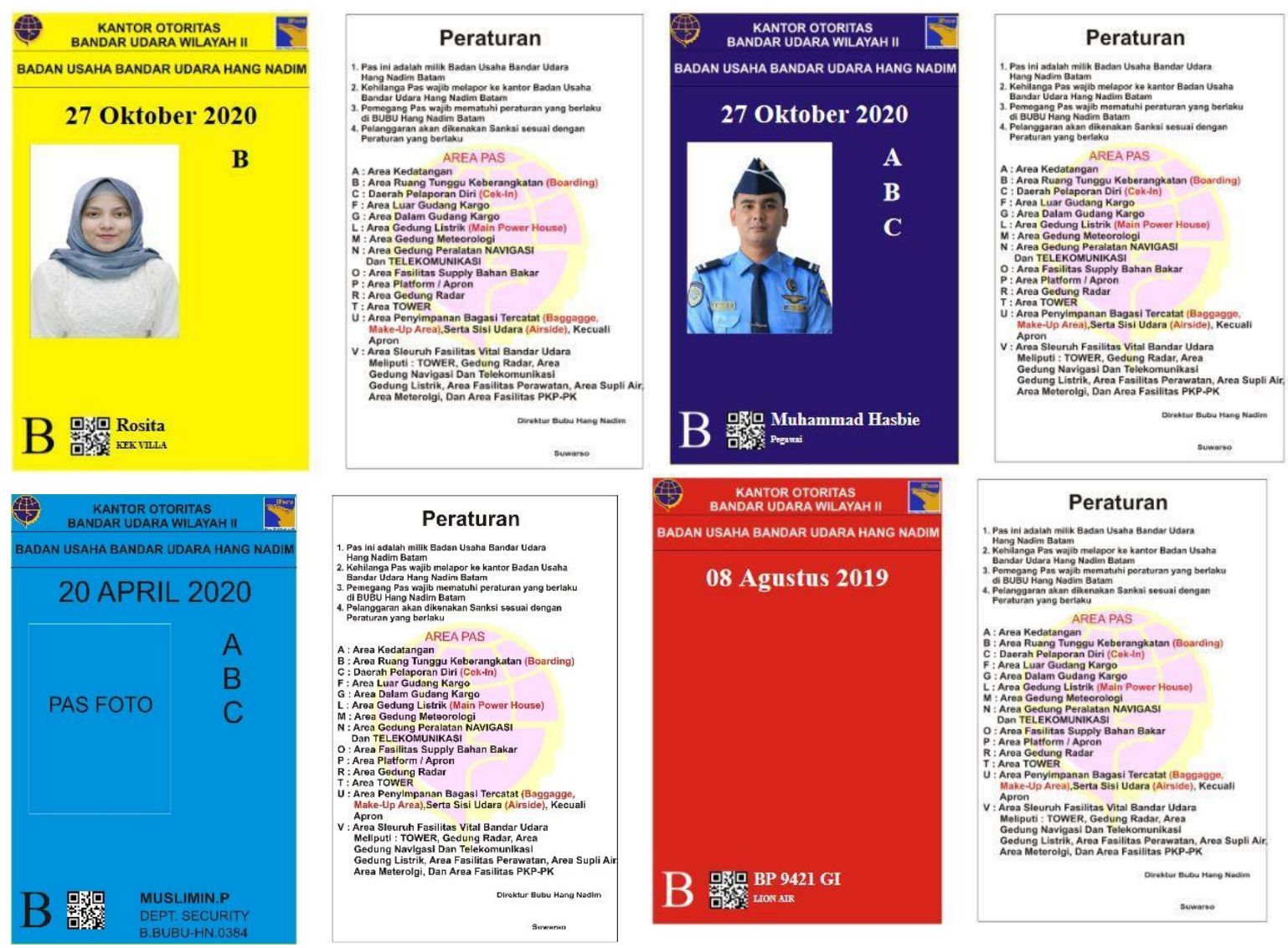

Gambar Contoh PAS Orang 
Tabel 5 Pengujian Login

Kasus dan Hasil Uji Benar (Data Benar

\begin{tabular}{|l|l|l|l|}
\hline Data Masukkan & Yang diharapkan & Pengamatan & Kesimpulan \\
\hline Input data login, & Jika data login valid, & Data Login Valid & Diterima \\
Contoh: & maka Admin akan & & \\
Username : Avsec & masuk ke Menu & & \\
Password : Avsec & dashboard. & & \\
\hline
\end{tabular}

Kasus dan Hasil Uji Salah (Data Salah)

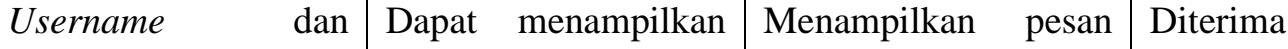

Password belum diisi pesan kesalahan kesalahan

atau salah

\section{HASIL Pengujian}

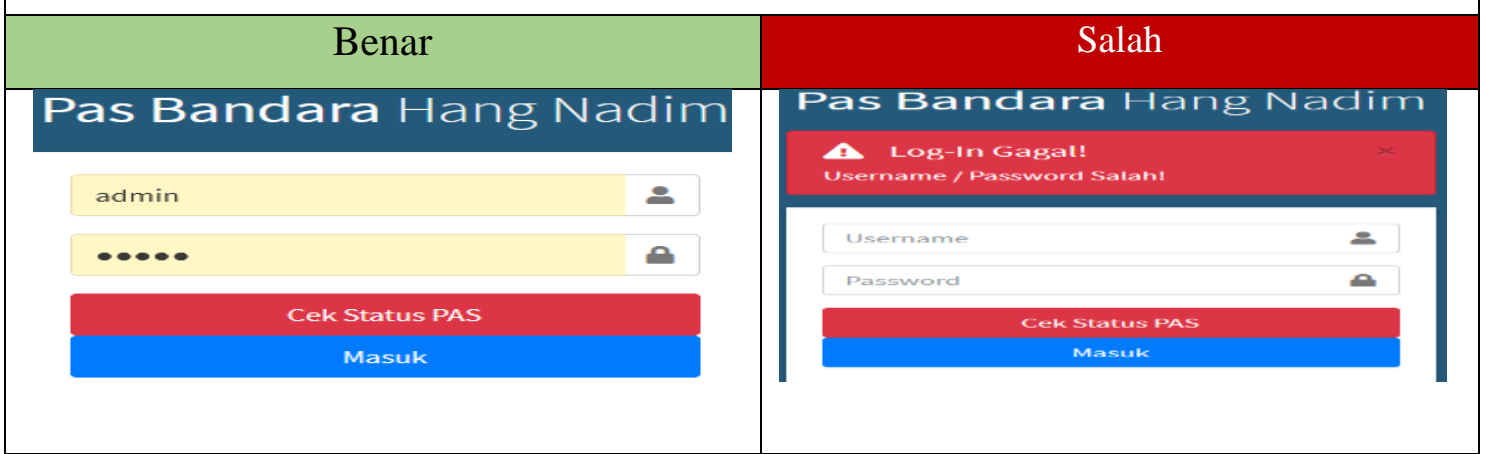

\section{Tabel 6 Pengujian Cetak PAS oleh Admin}

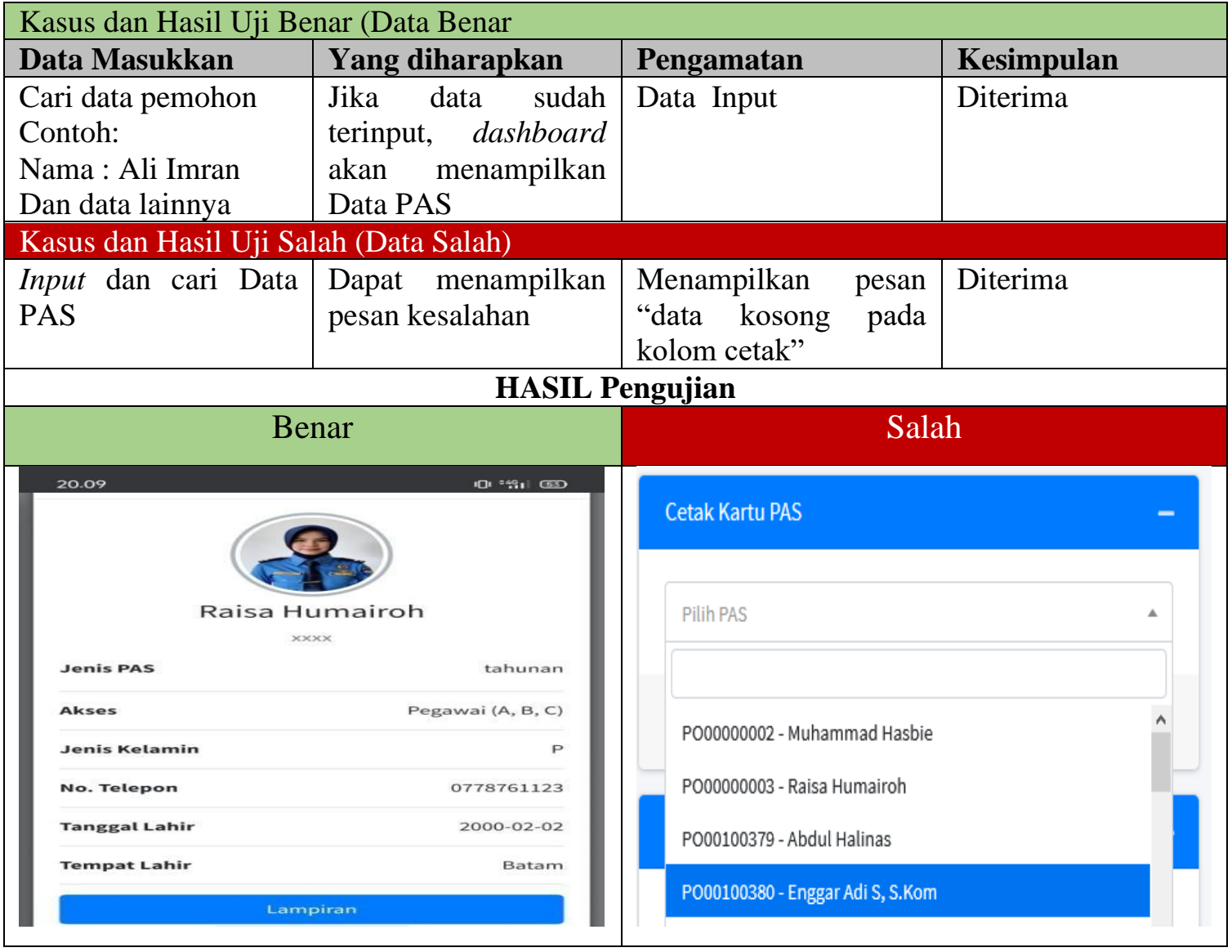




\section{KESIMPULAN}

Untuk meningkatkan kualitas pelayanan PAS di Bandara Hang Nadim Batam yang dikelola oleh badan pemerintahan daerah kepulauan Riau yaitu BUBU (Badan Usaha Bandar Udara) Batam, maka penulis memiliki 3 (tiga) aspek penilaian kesimpulan dari perancangan sistem Aplikasi Pelayanan PAS Bandara Hang Nadim Batam, yaitu sebagai berikut

1. Aspek Sumber Daya Manusia

Dari rumusan masalah penelitian ini perlunya sebuah sistem yang dapat membantu pihak Admin Screening dan Admin Avsec dalam pengarsipan database pemohon berbentuk sistem digital, sehingga ketika data akan dibutuhkan dapat lebih efektif, praktis dan efisien. Dan sistem yang dibangun penulis sudah sesuai dengan kebutuhan sistem pengelola Bandara Hang Nadim Batam dalam memonitoring data pengguna PAS.

2. Aspek Proses Pelayanan

Mempermudah pihak pemohon dari aspek individu ataupun perusahaan dalam melakukan pendaftaran atau pengajuan PAS, karena sudah dapat dilakukan secara online sistem. Sehingga mempercepat setiap proses daftar, validasi dan mempermudah kepemilikan PAS.

3. Aspek Sarana dan Prasarana

Kualitas Aplikasi Pelayanan permohonan kepemilikan PAS pada Bandara Hang Nadim Batam, memperkecil ruang lingkup antrian data pendaftar yang menumpuk di Admin Screening, karena peng-input-an data oleh admin screening sebelumnya dilakukan secara manual (Ms Excel), maka kini sudah diinput oleh pihak pemohon, admin screening tinggal verifikasi, validasi dan aktivasi PAS pengguna

\section{SARAN}

Dan berdasarkan kesimpulan diatas, penulis memberikan saran yang dapat dikembangkan oleh peneliti selanjutnya yang terkait atau tidaknya dengan Aplikasi PAS, yaitu sebagai berikut:

1. Sistem yang dibangun dapat dikembangkan dalam bentuk Mobile App, sehingga lebih fleksibel lagi dalam pengoperasian atau penggunaan Aplikasi ini.

2. Sistem PAS sebaiknya dapat terintegrasi dalam database Identity Card penduduk, sehingga memperkecil monitoring tingkat pencarian data penduduk.

3. Sistem reminder dan security penggunaan perlu dikembangkan pada Aplikasi PAS, sehingga pengelola BUBU yaitu Admin screening dapat mengetahui keberadaan kartu ini dalam memasuki setiap areal vital Bandara.

\section{DAFTAR PUSTAKA}

1) Abdillah, R., Kuncoro, A., \& Kurniawan, I. (2019). Analisis Aplikasi Pembelajaran Matematika Berbasis Android Dan Desain Sistem Menggunakan Uml 2.0 Analysis Mathematics Learning Apps Android Base And Designing System Using Uml 2.0.

2) Abdulloh, R. (2016). Easy \& Simple-Web Programming. Elex Media Komputindo.

3) Iswandy, E. (2016). Analisa Dan Perancangan Sistem Informasi Penagihan Purchasing Order Costumer Studi Kasus Pada Cv. Vertical Cipta Relasi Padang Dengan Metode Centralized Data Processing. Jurnal Teknoif, 4(2).

4) Irham, M., \& Supriadi, S. (2017). Perancangan Sistem Informasi Akademik Berbasis Web Pada Kampus Akademik Kerawatan Dan Kebidanan Kamanre Palopo. Prosiding Semantik 2017, 1(2), 188. 
5) Nadira, S., Nurlistiani, R., Kurniawan, H., Rahardi, A., \& Halimah, H. (2020). Penerapan Knowledge Management System (Studi Kasus: Spesialis Penyakit Jantung Dan Spesialis Penyakit Dalam Di Rsud Abdul Moeloek). Simada (Jurnal Sistem Informasi Dan Manajemen Basis Data), 2(2), 150-159.

6) Nasril, N., \& Aribah, G. (2018). Perancangan Sistem Informasi Liniertas Bidang Studi Pada Kementrian Pendidikan Dan Kebudayaan. Jurnal Lentera Ict, 4(1), 34-52.

7) Nurhayati, S., \& Ristanto, V. G. (2017). Sistem Informasi Pariwisata Provinsi Papua Berbasis Web. Semin. Nas. Aptikom, 3(1), 1-13.

8) Novianto, D. (2016). Implementasi Sistem Informasi Pegawai (Simpeg) Berbasis Web Menggunakan Framework Codeigniter Dan Bootstrap. Jurnal Ilmiah Informatika Global, 7(1).

9) Nurhayati, A. N., Josi, A., \& Hutagalung, N. A. (2017). Rancang Bangun Aplikasi Penjualan Dan Pembelian Barang Pada Koperasi Kartika Samara Grawira Prabumulih. Jurnal Teknologi Dan Informasi, 7(2), 13-24.

10) Persolita, W., Fauzansyah, F., Afidh, R. F. F., \& Elisawati, E. (2018). Aplikasi Web Penjualan Qubah Stainless Steel Di Mahkota Barokah Menggunakan Pemograman Php. Informatika, 10(1), 22-31.

11) Prayudha, R. A. E., \& Rochmawati, D. R. (2018). Perancangan Sistem Infomasi Pelayanan Publik Menggunakan Framework Lavarel \& Mysql Di Kecamatan Coblong Kota Bandung. Infokom, 6(2), 36-49.

12) Ponidi, P., \& Fitrajaya, S. (2017). Perancangan Sistem Informasi Pendataan Penduduk Berbasis Web Menggunakan Metode Waterfall Pada Kecamatan Gadingrejo. Jurnal Tam (Technology Acceptance Model), 4, 68-74.

13) Rahmawati, S., Andini, S., \& Zefriyenni, Z. (2018). Penerapan Game Education Untuk Meningkatkan Daya Ingat Belajar Pada Anak Usia Dini. Teknologi, 6(2).

14) Rasna, R. (2018). Evaluasi Kinerja Aplikasi Big Data Nosql Menggunakan Model Multi Formalisme Pada Kantor Dinas Komunikasi Dan Informatika Kabupaten Sarmi. Jurnal Ilmiah Teknik Dan Informatika, 3(1), 39-44.

15) Saputra, A. (2018). Sistem Informasi Manajemen Pendistribusian Barang Bekas Pada Ud. Yuli Mutiara Dengan Bahasa Pemograman Php Dan Database Mysql. Majalah Ilmiah, 25(2).

16) Saputra, W. D. (2018). Aplikasi Pendaftaran Kerja Pendaftaran Kejra Praktik (Kp) Pada Badan Pusat Statistik (Bps) Kota Palembang. (Doctoral Dissertation, Politeknik Negeri Sriwijaya).

17) Saraswati, E. I. (2018). Analisis Kualitas Pelayanan Customer Service Dalam Pengurusan Surat Keterangan Rencana Kota Di Unit Pelayanan Terpadu Satu Atap Kota Surabaya. Jurnal Aplikasi Administrasi, 19(1), 10-18.

18) Shalahuddin, M., \& Rosa, A. S. (2018). Rekayasa Perangkat Lunak (Terstruktur Dan Berorientasi Objek) Edisi Revisi. Bandung, Penerbit Informatika. 